\title{
Pemanfaatan Voki dalam Upaya Peningkatan Kemampuan Melafal Kata Dalam Bahasa Inggris pada Anak Usia 7-8 Tahun
}

\author{
Akhmad Subkhi Ramdani \\ Universitas Mohammad Husni Thamrin \\ akhmad.ramdani1988@gmail.com
}

\begin{abstract}
ABSTRAK
Berbicara dalam bahasa inggris bukanlah sesuatu yang mudah dilakukan bagi para penutur asing yang bukan pengguna asli bahasa inggris. Namun, bila upaya itu dilakukan sejak dini, hal ini bukanlah menjadi sesuatu yang mustahil untuk dilakukan. Hal ini dikarenakan anak usia dini mampu menirukan suara dan logat dari perkataan atau ucapan yang ia dengar. Tujuan dari penelitian ini adalah untuk mengetahui bagaimana Voki dapat membantu meningkatkan kemampuan melafal kata dalam bahasa inggris pada anak usia 7-8 tahun. Dalam penelitian ini, peneliti menggunakan metode Penelitian Tindakan Kelas. Penelitian ini dilakukan di Sekolah Dasar Negeri Jatimulya 01 dengan menggunakan siswa-siswi kelas satu sebagai sampelnya. Berdasarkan hasil penelitian, ditemukan bahwa para siswa-siswi mengalami peningkatan yang cukup berarti di setiap siklusnya, sehingga para siswa mampu melafalkan kata dalam bahasa inggris dengan baik dan benar pada akhir penelitian. Penelitian ini dapat disimpulkan bahwa Voki mampu digunakan untuk meningkatkan kemampuan melafal kata dalam bahasa inggris bagi anak usia 7-8 tahun.
\end{abstract}

Kata Kunci: Voki, melafal, anak usia 7-8 tahun

\section{PENDAHULUAN}

Melihat fenomena baik yang ada di dalam maupun di luar Indonesia yang sering kali ditemui yaitu bagaimana cara seseorang mengucapkan kata dalam bahasa inggris dengan logat asli mereka yang bukan merupakan pengguna asli bahasa inggris memang sudah tidak asing lagi. Hal ini dikarenakan seseorang tersebut telah tertanam atau terbentuk bagaimana sebuah kata itu diucapkan berdasarkan penegetahuan yang ia peroleh di lingkungan tempat ia dibesarkan. Hal yang harus diketahui terlebih dahulu adalah kemampuan berbicara merupakan kemampuan yang didapat oleh seseorang setelah ia mampu mendengar. Skinner (1957) menyatakan bahwa anak-anak mempelajari bahasa melalui prinsip-prinsip penguatan tingkah laku dengan menghubungkan kata-kata dengan makna, atau dapat disimpulkan menjadi: mendengar, meniru, menerima pengakuan, dan pengulangan. Di samping itu, Fraenkel (1984) menyatakan bahwa ada dua langkah utama untuk belajar bagaimana caranya mengucapkan sebuah bahasa: (1) tahap penerimaan / daftar. Pada tahap ini, anak-anak belajar membedakan suara dan pola yang signifikan dengan mendengarkan bahasa; (2) tahap produktif / berbicara. Pada tahap ini, anak-anak belajar berbicara atau menghasilkan apa yang telah mereka pelajari sebelumnya. Dalam hal ini, diketahui bahwa lingkungan merupakan faktor penting bagi seseorang untuk dapat berbicara dan memiliki logat atau cara pengucapan bahasa tersebut. Dengan kata lain, semakin banyak dan sering seseorang melakukan komunikasi di suatu lingkungan, maka akan semakin terpengaruh gaya bicaranya. Sehingga, dapat dikatakan bahwa kemampuan melafal yang erat kaitannya dengan berbicara juga sangat dipengaruhi dari apa yang didengar. Sebagai contoh, anak yang lahir dan dibesarkan di kota Solo, akan memiliki logat dan pelafalan orang Solo; anak yang lahir di kota Jakarta namun dibesarkan di kota Medan, maka akan membuatnya memiliki logat dan pelafalan orang Medan.

Seperti yang sudah dipaparkan sebelumnya, melafalkan kata dalam bahasa inggris bukanlah sesuatu yang mudah dilakukan terlebih lagi jika seseorang sudah memiliki logat dan pelafalan yang telah melekat pada dirinya. Hal ini dibuktikan dengan banyaknya orang yang salah atau keliru dalam mengucapkan kata dalam bahasa inggris. Namun, hal ini bukanlah sesuatu yang tidak dapat diatasi. Jalan yang dapat ditempuh adalah dengan upaya melakukan pelafalan kata dalam bahasa inggris sejak usia dini. Dengan seiringya perkembangan teknologi sekarang ini, sesorang tidak perlu lagi harus keluar negeri atau berbicara langsung dengan penutur asli bahasa inggris bila ingin mampu 
berbicara dan melafal dalam bahasa inggris. Voki yang merupakan alat pendidikan yang memungkinkan pengguna untuk membuat karakter berbicara sendiri. Voki dibuat oleh Oddcast dan terletak di Kota New York. Karakter Voki dapat dibuat agar terlihat seperti tokoh sejarah, kartun, hewan, dan bahkan diri kita sendiri. Disamping itu, Voki juga dapat merekam suara dengan mikrofon atau mengunggah file audio; dan karakter Voki dapat diemail, dibagikan di media sosial, atau disematkan di situs web. Dengan demikian Voki diharapkan dapat membantu meningkatkan kemampuan melafal kata dalam bahasa inggris.

\section{METODE}

Metode yang digunakan pada penelitian ini merupakan metode Penelitian Tindakan Kelas (PTK). Gregory, Kemmis, dan McTggart (1992) menyampaikan bahwa tindakan kelas digunakan sebagai upaya penyelidikan oleh seorang guru di dalam kelas yang dilakukan untuk meningkatkan pemahamannya tentang belajar-mengajar yang nantinya diharapkan dapat merubah kegiatan di kelas tersebut kearah yang lebih baik.

Tempat penelitian ini dilakukan di SDN Jatimulya 01, Bekasi, Jawa Barat yang dilakukan pada semester ganjil tahun ajaran 2018/2019 selama kurang lebih 4 bulan. Populasi dalam penelitian ini adalah siswa-siswi kelas 1A yang berjumlah 35 siswa dan guru bahasa inggrisnya. Terdiri dari 15 siswa dan 20 siswi. Sample dalam penelitian ini adalah seluruh siswa tersebut dan guru bahasa inggrisnya. Dengan demikian sample pada penelitian ini disebut sample total.

Dalam mengumpulkan data yang diperlukan bagi penelitian ini, peneliti menggunakan dua jenis instrument: instrument pemantau tindakan (catatan lapangan, lembar instrument pemantau tindakan, dan dokumentasi) dan instrument yang digunakan untuk mendapat data kemampuan melafal kata dalam bahasa inggris yang berupa lembar penilaian dalam bentuk tes. Data yang telah didapatkan kemudian dianalisis dengan menggunakan analisis kualitatif dan kuantitatif.

\section{HASIL DAN PEMBAHASAN}

Deskripsi dan Analisis Data.

Data yang diperoleh dalam penelitian ini ada dua macam: data mengenai proses pembelajaran dengan menggunakan Voki dan data hasil belajar berupa skor kemampuan melafal siswa. Oleh karena itu, analisis data penelitian ini meliputi analisis proses pembelajaran dan analisis hasil belajar siswa berupa kemampuan melafal kata dalam bahasa inggris.

1. Analisis pemantau tindakan pembelajaran menggunakan Voki.

Data yang diperoleh pada bagian ini didapatkan melalui lembar instrumen pemantau tindakan yang diisi oleh observer. Hasil analisis data pemantau tindakan pembelajaran dengan menggunakan Voki dapat dilihat pada tabel berikut :

Tabel Data hasil instrumen non tes siklus I.

\begin{tabular}{|c|l|c|c|c|}
\hline \multirow{2}{*}{ No. } & \multirow{2}{*}{ Jenis Data } & \multicolumn{2}{|c|}{ Siklus I } & \multirow{2}{*}{ Skor Maksimal } \\
\cline { 3 - 5 } & & Pertemuan I & Pertemuan II & \\
\hline 1. & Skor instrumen non tes & 20 & 23 & 30 \\
\hline 2. & Persentase instrumen non tes & $67 \%$ & $77 \%$ & $100 \%$ \\
\hline
\end{tabular}

Berdasarkan data pada tabel di atas, maka dapat disajikan dalam bentuk diagram berikut ini: 


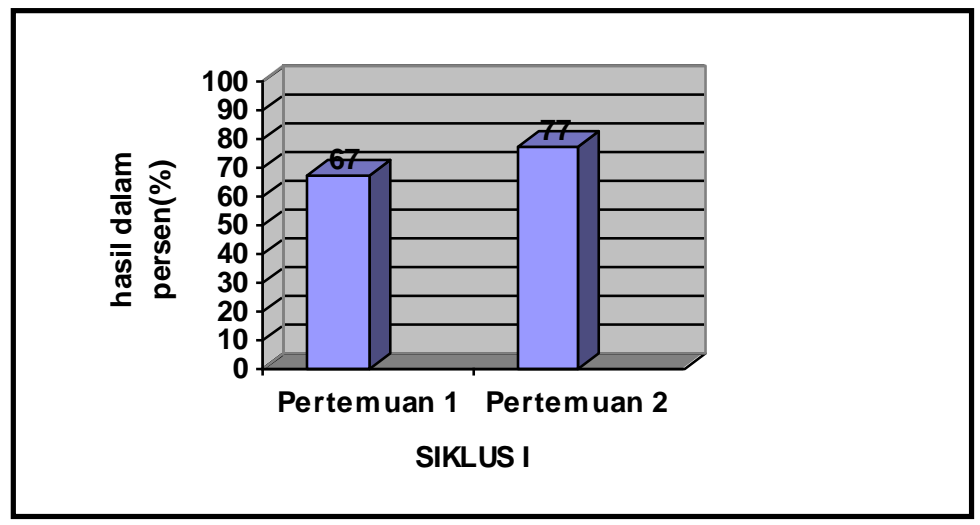

Gambar 1. Grafik hasil instrumen non tes siklus I.

Berdasarkan grafik di atas, diketahui bahwa pada pertemuan pertama masih ditemukan kesulitan, sehingga hasil yang didapat hanya mencapai angka 67\%. Namun, terlihat terjadi peningkatan pada pertemuan kedua, yakni $77 \%$ meskipun belum dapat dikatakan mencapai target yang diinginkan, yakni $100 \%$. Dengan kata lain, penelitian harus dilanjutkan pada siklus II.

Pada siklus II, berdasarkan data pada instrumen pemantau tindakan yang telah diberikan oleh obeserver, ditemukan peningkatan pada proses pembelajaran. Hal ini dikarenakan peneliti telah melakukan perbaikan pada beberapa masalah dan kekurangan yang ditemukan pada siklus I. Hasil analisis data pemantau tindakan pembelajaran dengan menggunakan Voki pada siklus II dapat dilihat pada tabel berikut:

Tabel Data hasil instrumen non tes siklus II.

\begin{tabular}{|l|l|l|l|l|}
\hline \multirow{2}{*}{ No. } & \multirow{2}{*}{ Jenis Data } & \multicolumn{2}{|c|}{ Siklus II } & \multirow{2}{*}{ Skor Maksimal } \\
\cline { 3 - 5 } & & Pertemuan I & Pertemuan II & \\
\hline 1. & Skor instrumen non tes & 27 & 30 & 30 \\
\hline 2. & Persentase instrumen non tes & $91 \%$ & $100 \%$ & $100 \%$ \\
\hline
\end{tabular}

Berdasarkan data yang tersajikan dalam tabel di atas, maka dapat sampaikan dalam diagram berikut.

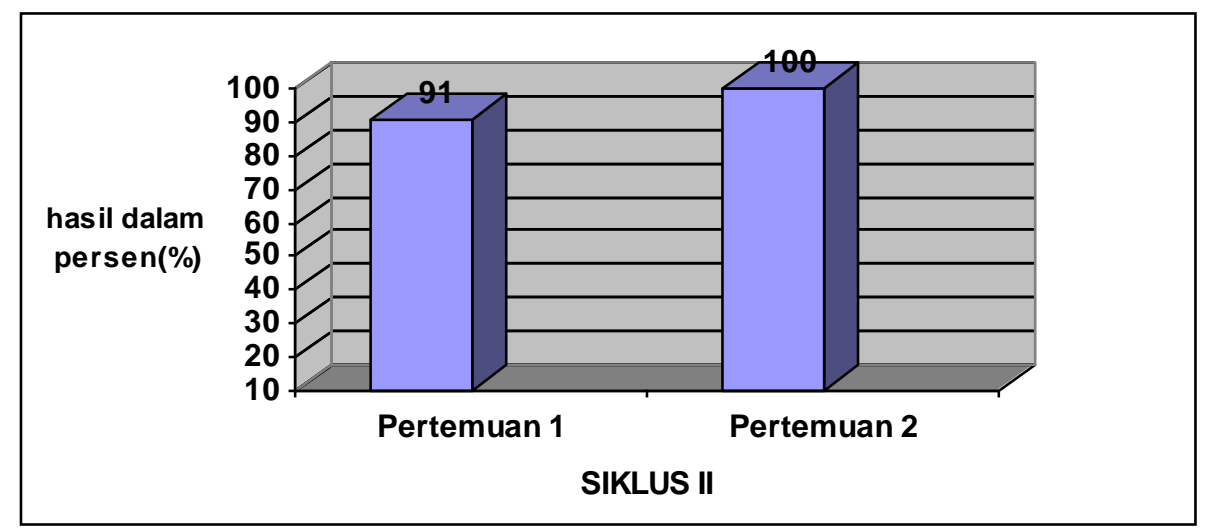

Gambar 2. Grafik hasil instrumen non tes siklus II.

Berdasarkan data yang tersajikan pada tabel dan grafik instrumen non tes pada siklus II, maka dapat diketahui bahwa terdapat peningkatan yang cukup signifikan. Hal ini dibuktikan dengan keberhasilan mencapai target yang diinginkan, yaitu sebesar 100\%. Pencapaian ini dapat terwujud 
karena peneliti telah memperbaiki dan mengatasi hambatan da kesulitan yang ditemui pada siklus I.

2. Analisis data berupa skor kemampuan melafal siswa.

Data pada bagian ini didapat melalui hasil tes tentang kemampuan melafal kata dalam bahasa inggris oleh siswa. Dalam hal ini, peneliti memberikan penilaian terhadap kemampuan melafal kata dalam bahasa yang didasarkan pada artikulasi dan intonasi. Target yang ingin dicapai dalam penelitian ini adalah $85.7 \%$ dari jumlah seluruh siswa kelas 1 atau 28 dari jumlah 35 siswa telah berhasil mencapai nilai KKM, yaitu 70. Berdasarkan data yang didapat pada pertemuan pertama siklus I, ditemukan bahwa 14 siswa atau $40 \%$ siswa dari total sample telah mencapai Kriteria Ketuntasan Minimal (KKM). Berlanjut pada pertemuan kedua, ditemukan bahwa 24 siswa atau $68.6 \%$ dari jumlah total sample telah mencapai KKM. Hal ini menunjukkan adanya peningkatan yang cukup berarti dalam upaya peningkatan kemampuan melafal kata dalam bahasa inggris.

Data hasil tes tersebut dapat dilihat pada tabel di bawah ini.

Tabel Data hasil instrumen tes siklus I.

\begin{tabular}{|l|l|l|l|l|}
\hline \multirow{2}{*}{ No. } & \multirow{2}{*}{ Jenis Data } & \multicolumn{2}{|c|}{ Siklus I } & \multirow{2}{*}{ Target } \\
\cline { 3 - 4 } 1. & $\begin{array}{l}\text { Skor instrumen tes } \\
\text { (banyaknya siswa yang telah } \\
\text { mencapai KKM) }\end{array}$ & 14 siswa & 24 siswa & 30 siswa \\
\hline 2. & Persentase instrumen tes & $40 \%$ & $68.6 \%$ & $85.7 \%$ \\
\hline
\end{tabular}

Data tersebut dapat juga disajikan dalam bentuk grafik yang bentuknya dapat dilihat berikut ini :

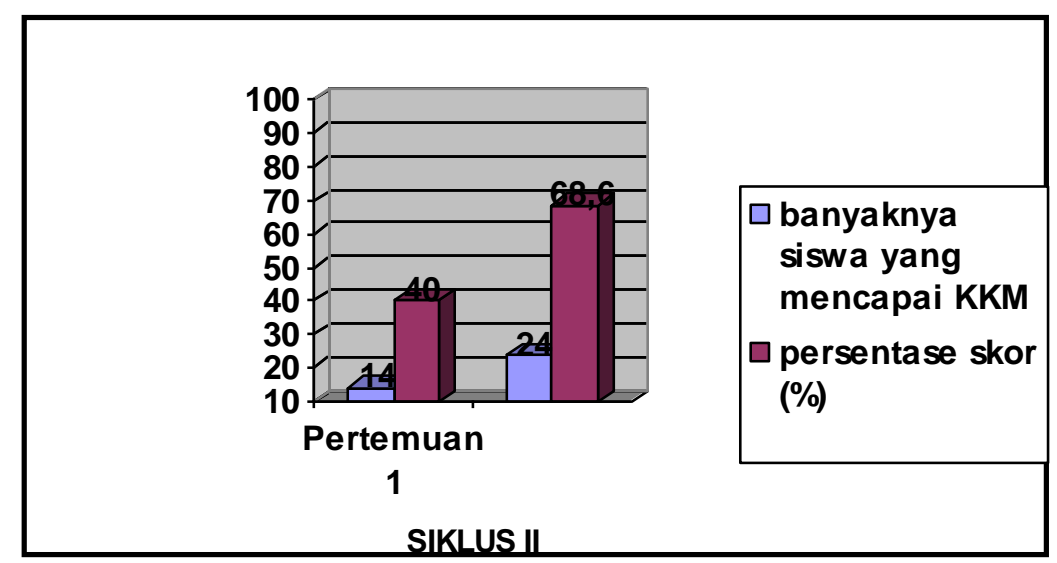

Gambar 3. Grafik hasil instrumen tes siklus I.

Berdasarkan data yang tergambar pada grafik di atas, terlihat bahwa skor kemampuan melafal siswa masih belum mencapai target pada siklus I, sehingga penelitian ini harus dilanjutkan pada siklus II.

Pertemuan juga dilaksanakan sebanyak dua kali pada siklus II. Pada pertemuan pertama di siklus II, siswa yang telah mencapai nilai KKM bertambah menjadi banyaknya siswa yang telah mencapai nilai KKM meningkat menjadi 26 orang atau 74.3\%. Peningkatan juga terjadi pada akhir pertemuan di siklus II. Siswa yang berhasil mencapai target KKM bertambah menjadi 33 orang atau $94.3 \%$. Dengan tingkat perolehan hasil yang mencapai angka $94.3 \%$, hal ini juga berarti bahwa upaya peningkatan kemampuan melafal kata dalam bahasa inggris dengan menggunakan 
Voki berhasil, bahkan mampu melebihi target yang telah ditetapkan. Data tersebut dapat disajikan dalam bentuk tabel seperti di bawah ini.

Tabel Data hasil instrumen tes siklus II.

\begin{tabular}{|l|l|l|l|l|}
\hline \multirow{2}{*}{ No. } & \multicolumn{1}{|c|}{ Jenis Data } & \multicolumn{2}{|c|}{ Siklus I } & \multirow{2}{*}{ Target } \\
\cline { 3 - 4 } 1. & $\begin{array}{l}\text { Skor instrumen tes } \\
\text { (banyaknya siswa yang telah } \\
\text { mencapai KKM) }\end{array}$ & 26 siswa & 33 siswa & 35 siswa \\
\hline 2. & Persentase instrumen tes & $74.3 \%$ & $94.3 \%$ & $80 \%$ \\
\hline
\end{tabular}

Data pada tabel di atas juga dapat disajikan dalam bentuk grafik seperti di bawah ini

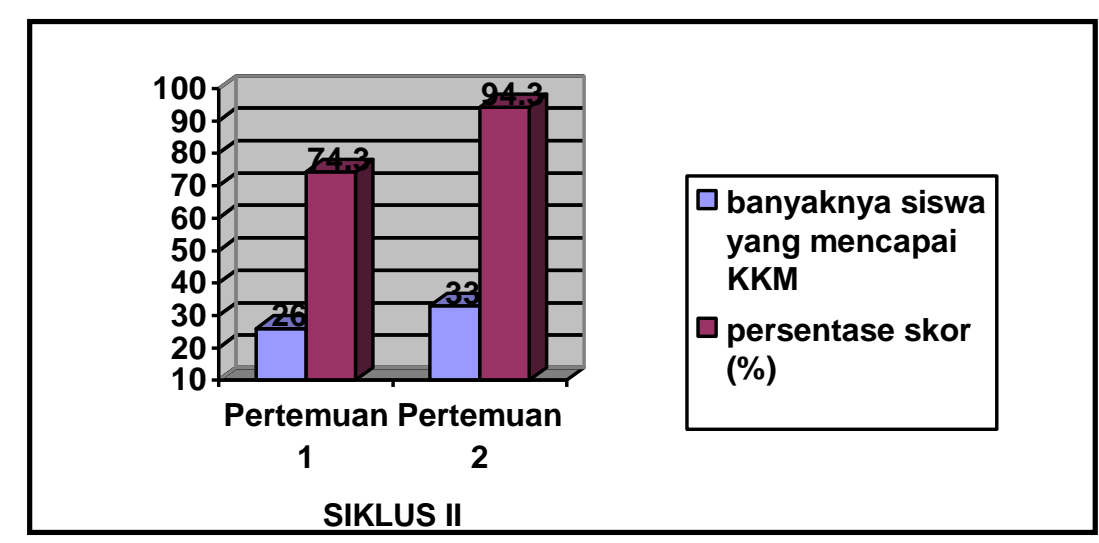

Gambar Grafik skor kemampuan melafal kata dalam bahasa inggris siswa siklus II.

Pembahasan.

Berdasarkan hasil analisis data yang telah dijabarkan oleh peneliti sebelumnya, ditemukan bahwa adanya peningkatan pada setiap hasil tesnya. Hal ini dibuktikan dengan table hasil data tes pada sikulus I dan II di bahawah ini.

Tablel Peningkatan kemampuan melafal kata dalam bahasa inggris.

\begin{tabular}{|c|l|c|}
\hline Siklus & Data setiap siklus & Persentase \\
\hline \multirow{2}{*}{ siklus I } & pertemuan 1 & $40 \%$ \\
\cline { 2 - 3 } & pertemuan 2 & $68.6 \%$ \\
\hline \multirow{2}{*}{ siklus II } & pertemuan 1 & $77 \%$ \\
\cline { 2 - 3 } & pertemuan 2 & $86 \%$ \\
\hline
\end{tabular}

Sedangkan hasil pemantauan pembelajran dengan menggunakan Voki selama dua siklus terlihat pada table di bawah ini. 
Tabel Peningkatan hasil tindakan kelas dengan menggunkan Voki.

\begin{tabular}{|c|l|c|}
\hline Siklus & Data setiap siklus & Persentase \\
\hline \multirow{2}{*}{ siklus I } & pertemuan 1 & $67 \%$ \\
\cline { 2 - 3 } & pertemuan 2 & $77 \%$ \\
\hline \multirow{2}{*}{ siklus II } & pertemuan 1 & $91 \%$ \\
\cline { 2 - 3 } & pertemuan 2 & $100 \%$ \\
\hline
\end{tabular}

Berdasarkan data dari dua table yang telah dihadirkan di atas, diketahui bahwa terdapat peningkatan kemampuan melafal kata dalam bahasa inggris dengan menggunakan Voki. Dengan kata lain, peningakatan ini menunjukkan bahwa identifikasi dan analisis masalah yang telah dilakukan peneliti bersama kolaborator ditemukan pemecahannya dan menunjukkan hasil yang optimal, sesuai dengan target yang diinginkan. Sehingga, hipotesis tindakan yang diharapkan berhasil, yaitu penggunaan Voki dapat meningkatkan kemampuan melafal kata dalam bahasa inggris oleh anak usia 7-8 tahun.

\section{KESIMPULAN}

Berdasarkan data dari hasil penelitian dan pembahasan yang telah paparkan, dapat disimpulkan bahwa peningkatan kemampuan melafal kata dalam bahasa inggris pada siswa kelas satu atau usia 7-8 tahun dengan menggunakan media Voki dapat dilakukan.

Hal ini dikarenakan: (1) penggunaan media Voki dalam upaya peningkatan kemampuan melafal mampu memeberikan siswa contoh nyata akan logat atau gaya bahasa dari penutur asli bahasa inggris., (2) dengan penggunaan media Voki, siswa terlibat secara aktif karena sangat menarik bagi anak-anak yang pada dasarnya sangat menyukai animasi. (3) dengan penggunaan media Voki, guru tidak lagi mengalami kesulitan untuk menyebutkan kata dalam bahasa inggris karena semua hal itu bisa dilakukan oleh animasi, (4) dengan penggunaan media Voki, siswa menjadi semangat dan termotivasi dalam mempelajari bahasa inggris terutama kemampuan berbicara karena menggunakan media animasi, (5) penggunaan media Voki memberikan kesempatan bagi untuk terus mencoba dan mengulang kata-kata yang ingin didengar tanpa ada perubahan dalam setiap pengulangannya.

\section{DAFTAR PUSTAKA}

Brown, H.D. (2002). Principles of Language Learning and Teaching. 4th ed. New York: Longman.

Conroy, M.A. Internet tools for language learning: University students taking control of their writing(2010). Australasian Journal of Educational Technology. http://www.ascilite.org.au/ajet/ajet26/conroy.html(accessed November 19, 2018).

Creswell, J.W., \& Urbom, J. (1997). Validity (verification) in qualitatitve research: Perspectives, terms, procedures, and methodologies. Unpublished manuscript, Department of Educational Psychological Psychology, University of Nebraska-Lincoln.

Creswell, J.W. (2007) Qualitative inquiry \& research design: Choosing among five approaches (2nd ed.).

Fraenkel, D.G (1984). Learning How to Pronounce a Language. London.

Kemmis, S \& Mc Taggart, R. (1992). The Action Research Planner. Australia: Deakin University Press.

Krashen, Stephen D. (1981). Second Language Acquisition and Second Language Learning. California: Pergamon Press Inc.

Miriam, Vargas. (2016, January 12). What is voki?. Retrieve from https://prezi.com/xybb2brbi9v/what-is-voki/

Shanty, Ch.Djonhar. (2012). Introduction to Language Acquisition: The acquisition of English as a Foreign Language. Jakarta: Uhamka Press.

Skinner, B.F. (1957). Verbal Behavior. New York: Appleton-Century-Croft, Inc.

Suparman, U. (2009). Qualitative Research for Language Teaching and Learning: (Qualitative Inquiry and Research Design) Jakarta: Uhamka. 